\title{
One Health Approach in the Understanding of Possible Diseases Transmission by Fruits Bats
}

Didik Pramono $^{1, b)}$, Supratikno ${ }^{2, c)}$, I Nengah Donny Artika ${ }^{1, d)}$, Faisal Tanjung ${ }^{1, e)}$, Ni Luh Putu Ika Mayasari $^{3, \text { f) }}$, Etih Sudarnika ${ }^{3, g)}$, Abdul Zahid Ilyas ${ }^{3, \text { h) }}$, Chaerul Basri, ${ }^{3, \text { i) }}$, Srihadi Agung Priyono ${ }^{2, \text { a) }}$

${ }^{1}$ National Zoonoses Center, Faculty of Veterinary Medicine, Bogor Agricultural University

${ }^{2}$ Departmen of Anatomy, Physiology, and Pharmacology, Faculty of Veterinary Medicine, Bogor

Agricultural University

${ }^{3}$ Department of Animal Disease and Veterinary Public Health, Faculty of Veterinary Medicine, Bogor Agricultural University

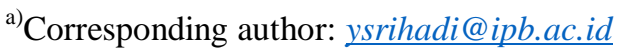

b)didikpramonodvm@gmail.com

\begin{abstract}
About $75 \%$ of contagious diseases in the world are classified as zoonosis. One among wild animals suspected to spread the disease is bat. Bats have an important role in the spreading of viral diseases. Fruit bat is among bat species that may potentially transmit diseases to human. The transmission of diseases to human population should be associated with the ecology, behavior of bats and bat-human interaction. We observed the fruit bats ecology and behavior in their roosting sites during daytime (from sunrise to sunset) and in human villages area during night. The observation was conducted in Leuweung Sancang National Park, Garut, West Java. Bats often moved around to find a roost that meets their needs. In daytime bats hanged on cave near of beach for taking a rest and in night bats came to plantation in human villages for food. The plantation were cottonwood tree, guava tree, sapodilla tree, mango tree and rubber tree. The dominant behavior activity of bats in groups during daytime was sleeping. Other activities of bats in its group were aggression, self-grooming, wings flapping, biting, playing, fighting and maternal care. The solitary behavior of bats including sleeping and hang-relax or relaxing. The existence of bats interactions (direct contact and body fluid exchange) between individuals in the social behavior and in solitary behavior suggested a possibility of transmission of the agents among the bats such as parasite, bacteria and virus. Based on the observation, human ever had direct contact with bats such as catching and eating the bats or indirectly through contact with the bat feces and or eating the fruit eaten partly by the bats. These direct and indirect contact between human and bat may suggest a possibility of disease transmission to human.
\end{abstract}

Keywords: Bat, Behavior, One Health, Transmission, Zoonoses

\section{INTRODUCTION}

About $75 \%$ of contagious diseases in the world were classified as zoonotic. One among wild animals suspected to spread the diseases is bat. Bats have been known as reservoir for rabies virus for a long time [1]. Recently, Research in several countries around of Indonesia such as Vietnam, Cambodia, Thailand and Philippines reported that high level of rabies virus exposure in bats population in its region happened $[2,3,4,5]$. Bats have also been considered as natural hosts of many common human and animal viruses, such as measles, mumps, parainfluenza, canine distemper and hepatitis $\mathrm{C}$ viruses $[6,7]$. However, bats have caught our attention very recently, 
due to their association with several severe emerging infectious diseases. Currently, bats have been considered to be natural reservoirs of SARS-CoV, MERS-CoV, NiV, HeV, Ebola virus, and Marburg viruses. These viruses have attracted global attention in recent years for their severity and/or easy transmission [8].

The high level transmission of diseases to human population should be associated with the ecology, behavior of bats and bat-human interaction. Because of it, to know how the transmission of diseases between them (bats in its group), animals and human in natural roosting site, we have to know the behavior and ecology-related of bats in roosting site. In Indonesia, there are not many information about possibility of virus transmission from bats to human. Almost throughout the year, bats are entering village area, especially when the fruit season to find fruit for food. During the entrance to the village area, Villagers ever had contact with bats and suggest a possibility of transmission of diseases from bats such as virus, bacteria and parasite. The paper will review the use of one health approach in the understanding of possible diseases transmission by fruit bats.

\section{ONE HEALTH AND ZOONOSES}

The one health approach plays a significant role in the prevention and control of zoonoses. World Health Organization (WHO) [9] and [10] reveal that about 75\% of new emerging infectious diseases are classified as zoonotic. One health is defined by the One Health Commission [11] as "the collaborative effort of multiple disciplines to obtain optimal health for people, animals, and our environment." In another definition, the One Health Initiative Task Force (OHITF) [12] defines one health as "the promotion, improvement, and defense for the health and well-being of all species by enhancing cooperation and collaboration between physicians, veterinarians, and other scientific health professionals and by promoting strengths in leadership and management to achieve these goals." Infections that are naturally transmissible from vertebrate animals to humans and vice versa are classified as zoonoses [13]. In addition to having potentially catastrophic impacts on human health and life, zoonotic diseases are associated with significant economic losses to the affected economies as a whole [14]. Zoonotic diseases have both direct and indirect effects on livestock health and production [15]. Indirect effects include the risk of human disease, the economic impact on livestock producers through barriers to trade, the costs associated with control programs, the increased cost of marketing produce to ensure they are safe for human consumption and the loss of markets because of decreased consumer confidence [16, 17].

\section{BAT CHARACTERISTICS}

Bats have many features that enable to carry a diversity of viruses. Bats account for about $25 \%$ of all mammalian species, making them the second largest order of mammals $[18,19]$. Bats (Order Chiroptera) can be classified into two suborders: the Mega chiroptera or mega bats and micro chiroptera or micro bats [20]. Mega bats eat fruit and micro bats live on insects, small mammals, fish or blood. Mega bats have no echolocation and micro bats possess echolocation. Bat generally provide for ecosystem services, such as arthropod balance, seed dispersal and pollination. However, bats have been receiving high attention as potential reservoirs for zoonotic diseases following recent identification research of their involvement with some diseases like coronaviruses, Ebola and Marburg filoviruses, Hendra and Nipah paramyxoviruses [21]. Characters that may make bats suited to hosting more viruses include relatively long lifespans for their body size [22], 
bats may keep viruses circulating among the bat population. Bats are social animals, millions of individuals can be found in a single cave; flight, in some species of bats can move over long distances, many bat species are colony living, some living in dense roosting site [23,24]. The large number of bats in a colony with physical proximity facilitates viral transmission among bats, maintaining viruses circulating stably among bats. A study showed that several emerging viruses could be amplified in a bat colony during the breeding season [25].Beside it, roosting sites can be house for multiple bat species [26, 27].

The eating behavior of bats can also be linked to viral transmission. Fruit bats can not take a large amount of food, and to meet their demand for energy, instead of swallowing, they just chew to absorb sugars and higher energy components, and spit out the partially digested fruits. Discarded fruits contaminated by viruses in bat saliva may be eaten by other animals and infect them [28]. In addition, despite their small size, bats have a relatively long life span, most of the species live for 10-20 years and some can live up to 30 years [29]. The longevity of bats also increases the possibility of viral dispersal.

Many species of bats have per domestic habits, roosting in houses and other buildings, as well as trees in dense urban areas, leading to frequent human contact with bat excreta [30, 32]. Bat-human contact is also increasing in recent decades increased use of bats as bush meat $[33,35]$. Bat live in habit various ecological niches, including trees, caves, and man-made structures, such as tunnels, deserted houses, even occupied houses in rural areas. The worldwide distribution and various habitats of bats pose the public to a general risk of infection with bat-borne viruses. Bats are special as the only mammals that can actually fly. Bats fly in their daily quest for food and seasonal migration, some of which can fly up to nearly $2000 \mathrm{~km} \mathrm{[36].} \mathrm{The} \mathrm{ability} \mathrm{to} \mathrm{fly} \mathrm{enables} \mathrm{bats} \mathrm{to} \mathrm{carry}$ viruses to distant areas.

\section{BAT-HUMAN INTERACTION}

Viruses discussed above tend to be restricted to certain geographic regions with a particular bat reservoir, such as $\mathrm{HeV}$ and $\mathrm{NiV}$ associated with flying foxes in Australia and Southeast Asia. Most bat population roost in tropical forests or caves. There are not many information about how bats transmit viruses to human. Below are the hypotheses of how bat-borne viruses are transmitted to humans [8].

\section{Intermediate Host}

The intermediate hosts theory is a popular theory for bats to transmit viruses to humans, which are in close contact with humans and can amplify viruses. When fruit bats eat fruit, they contaminate the fruit with viruses in their saliva and urine; discarded fruit fall to the ground and is consumed by intermediate hosts, such as pigs, horses, and nonhuman primates; humans become infected by contact with or consuming products of the intermediate animal hosts. For example: flying foxes transmitted $\mathrm{NiV} / \mathrm{HeV}$ to human in Southeast Asia and tropical Australia [37]. HeV is endemic in flying foxes in Australia. $\mathrm{HeV}$ spills over from bats to domestic animals, primarily horses, which amplify the virus and subsequently infect humans [38]. Fruit contaminated by bats is also thought to transmit Ebola virus to apes in Central Africa [39]. In the case of the 2003 SARS outbreak in China, the transmission of SARS-CoV from bats to humans was made possible by the special taste for wildlife cuisine, including civets [40]. As for MERS in Middle East, dromedary 
camels are hypothesized as intermediate animals to transmit MERS-CoVs from bats to humans [41].

\section{Direct Contact with Bat}

Although bats are rarely in contact with people, people may become infected with bat-borne viruses by consuming bat meat. Consumption of infected bats may transmit such bat-borne viruses as Ebola virus to humans. In 2007 Ebola hemorrhagic fever reemerged in the Democratic Republic of Congo (DRC) causing 186 deaths. Epidemiological investigation showed that the outbreak was due to consumption of fruit bats, which were migrating towards the southeast and were massively hunted as a major source of protein by local villagers [39]. Consumption of well-cooked bat meat may not be a problem, but the handling of bats may increase the risk of infection. In addition, accidental bite by a bat may result in Rabies. One example is the case of an elderly man in South Africa who died of Duvenhage virus (DUVV) infection after being scratched by a bat [43].

\section{Aerosol transmission}

Bats with a large population roost in caves and viruses may contaminate air in caves where bats live and people may become infected by inhaling viruses in the air when they enter caves. Research showed that Cynomolgus macaques could suffer a lethal viral hemorrhagic fever after exposure to small-particle aerosols containing MARV-Angola [44]. There was are port that humans were infected by Marburg virus after visiting or working in caves in Africa, and transmission by aerosol could not be excluded as a possible mode of infection [45].

\section{STUDY USING ONE HEALTH APPROACH}

We observed bats on roosting site during daytime and night. Our data showed that many population of bats hanged on roosting site and did some behavior. Bats often moved around to find a roost that meets their needs. In daytime bats hanged on cave near of beach for taking a rest and in night bats came to plantation in human villages for food. The plantation were cottonwood tree, guava tree, sapodilla tree, mango tree and rubber tree. Behavior of bats divided into two group of behavior: solitary behavior and social behavior. For solitary behavior sleeping is most activity that bats did. Sometimes bats moved from one group to another group. Bats did another behavior such as courtship, aggression, bite, fight and play each individual. The existence of bats interactions between individuals showed that social behavior and in solitary behavior suggested a possibility of transmission of the agents among the bats such as parasite, bacteria and virus. The bats interactions are direct and indirect contact. Direct contact such as biting, fighting, mating or playing among them. Indirect contact such as fluid exchange after mating or share food among them. During night based on this survey on human, we noted possible contact between bat and human through bat bite, bat mate consumed by human, indirect contact like human eating the discarded fruit eaten partly by the bats. 


\section{CONCLUSION}

By using one health approach in the study on behavior and ecology of fruit bats, we noted that a possible transmission of diseases can happen among bats because of their social-behavior and to human because of the contact either directly or indireclty.

\section{REFERENCES}

1. Pawan JL, 1959, Caribb, Med. J. 21, 137-156.

2. Marini RP, Cassiday PK, Venezia J, Shen Z et al. 2014, Emer Infect Dis. 20(1), 161-163.

3. Reynes J, Molia S, Hout S et al. 2004, Emer Infect Dis. 10(12), 2231-2234.

4. Lumlertdacha B, Boongird K, Wanghongsa S et al. 2005, Emer Infect Dis. 11(2), 232-234.

5. Arguin, PM. Lillibridge KM, Miranda MEG et al. 2002, Emer Infect Dis. 8(3), 258-262.

6. Drexler, J.F., Corman, V.M., Muller et al. 2012, Nat. Commun. 3, 796.

7. Quan, P.L., Firth, C., Conte, J.M. et al. 2013, Proc. Natl. Acad. Sci. U.S.A .110 (20), 81948199.

8. Han HJ, Wen HL, Zhou CM et al. 2015, Virus research 205, 1-6

9. WHO. Combating Emerging InfectiousDiseases in the South East Asia Region. 2005, http://www.searo.who.int/entity/emerging diseases/documents/SEA CD 139/en/index.html. (accessed February 20th, 2017)

10. J. P. Graham, J. H. Leibler, L. B. Price et al. 2008, Public Health Reports. 123 ( 3), 282-299

11. One Health. (n.d.) One Health Commission, 2010, http://www.onehealthcommission.org/. (accessed February 20th, 2017)

12. OHITF, 2008, One Health: A New Professional Imperative-OneHealth Initiative Task Force. American Veterinary Association.

13. WHO, 2009, Annual report. Zoonoses and Veterinary Public Health. Brucellosis. Geneva: WHO Document Production Services.

14. World Bank, 2010, People, pathogens and Our planet volume 1: towards a One health approach for controlling zoonotic diseases. Washington: World Bank.

15. Smits HL, Cutler SM. 2002, African J Biotech. 3(12), 631-6.

16. McDermott JJ, Arimi SM. 2002, Vet Microbiol. 90, 111-34.

17. Perry BD, Randolph TF, McDermott JJ et al. 2002, http://www.ilri.org/InfoServ/Webpub/fulldocs/investigating/Animal/Book1/PDF_chapters/Book 1_Contents.pds (accessed February 20th, 2017).

18. Jones, K.E., Bininda-Emonds, O.R., Gittleman et al. 2005, Evolution. 59 (10), 2243-2255.

19. Turmelle AS, Olival, KJ. 2009, Ecohealth. 6 (4), 522-539.

20. Simmons NB. 2005, The Johns Hopkins UniversityPress. (3), 312-529.

21. Calisher CH, Childs JE, Field HE et al. 2006, Clin. Microbiol. Rev. 19, 531-545.

22. Munshi-South J, Wilkinson GS. 2010, Ageing Res. Rev. 9, 12-19.

23. Constantine DG. 1967 Activity patterns of the Mexican free-tailed bat. Albuquerque. University of New Mexico Press.

24. Betke M et al. 2008, J. Mammal. 89, 18-24.

25. Drexler JF, Corman VM, Wegner T, et al. 2011, Emerg. Infect. Dis. 17 (3), $449-456$

26. Kuzmin IV, Mayer AE, Niezgoda M et al. 2010, Virus Res. 149, 197-210.

27. Kunz TH. 1982. Ecology of bats. New York (US): Plenum Press.

28. Dobson AP. 2005, Sci-ence 310 (5748), 628-629

29. Brunet-Rossinni AK, Austad SN. 2004, Biogeron-tology. 5 (4), 211-222. 
30. Hayman DTS, Fooks AR, Horton D et al. 2008, Emerg. Infect. Dis. 14, 926-928.

31. O’Shea TJ, Neubaum DJ, Neubaum MA. 2011, Urban Ecosyst. 14, 665-697.

32. Plowright RK, Foley P, Field HE et al. 2011, Proc. R. Soc. B 278, 3703-3712.

33. Mickleburgh S, Waylen K, Racey P. 2009, Oryx. 43, 217-234.

34. Kamins AO, Restif O, Ntiamoa-Baidu Y et al. 2011, Biol. Conserv. 144, 3000-3008.

35. Pulliam JRC et al. 2012, J. R. Soc. Interface. 9, 89-101.

36. Fleming TH, Eby P. 2006, Ecology of Bat Migration. In: Kunz, T.H., Fenton, M.B.(Eds.), Bat Ecology, Chicago (US), The University of Chicago Press

37. Chua KB, Chua BH, Wang CW. 2002, J. Pathol. 24 (1), 15-21.

38. Murray K, Selleck P, Hooper P et al. 1995, Science. 268 (5207), 94-97.

39. Leroy EM, Epelboin A, Mondonge V et al. 200, Vector Borne Zoonotic Dis. 9 (6), 723-728.

40. Liu J. 2003, Science. 302 (5642), 53.

41. Memish ZA, Cotten M, Meyer B et al. 2014. Emerg. Infect. Dis. 20 (6), 1012-1015.

42. Reusken CB, Farag EA, Jonges M et al. 2014, Euro Surveill,19(23)

43. Adjemian J, Farnon EC, Tschioko F. 2011, J. Infect. Dis. 204(3), 1537-6613.

44. Alves DA, Glynn AR, Steele KE. 2010, Vet. Pathol. 47(5), 831-851.

45. Timen A, Koopmans M, 2008. Marburg Hemorrhagic Fever-The Netherlands exUganda.

ProMed. 